УДК 343.13

DOI https://doi.org/10.32844/2618-1258.2019.3-2.28

КОТОВА О.С.

\title{
ВИНЕСЕННЯ ПОСТАНОВИ ПРО ВИЗНАННЯ РЕЧОВИМ ДОКАЗОМ ЯК ПЕРЕДУМОВА АРЕШТУ МАЙНА
}

\begin{abstract}
У статті розглядається актуальне для сучасної правозастосовної практики питання винесення постанови про визнання речовим доказом майна як передумови накладення арешту на це майно. Узагальнення правозастосовної практики показує, що в Україні відсутня єдність підходів слідчих, прокурорів, слідчих суддів і науковців щодо вирішення цього питання. Тлумачення відповідних норм кримінального процесуального законодавства також не дає можливості зробити висновок щодо етапності накладення арешту на майно, що зумовлюється відсутністю правової визначеності у нормах права. Контраргументацією необхідності винесення постанови про визнання об'єкта речовим доказом є думки вчених, в яких вони зазначають, що така модель формально не суперечить законодавству, проте не відповідає новітній концепції правової природи доказів, відповідно до якої під час здійснення досудового розслідування сторони збирають матеріали про джерела майбутніх доказів, які можуть визнаватися доказами за результатами їх оцінки лише судом.

Крім того, серед учених є думка, що, прагнучи виносити постанову про визнання предметів речовими доказами, сторона обвинувачення так зберігає практику, яка існувала за КПК України 1960 р., згідно з якою слідчий і прокурор визнавали доказами дані, зібрані й оцінені ними. Проте така практика є застарілою та не відповідає сучасному законодавству. Автор статті на підставі узагальнення судової та слідчої практики доходить висновку про доцільність і виправданість винесення постанови про визнання предметів (майна) речовими доказами перед вирішенням питання про накладення арешту на таке майно та наводить на підтвердження цієї думки належну аргументацію. Зокрема, підкреслюється, що арешт майна допускається з метою забезпечення збереження речових доказів, тобто на момент судового розгляду питання про накладення арешту на майно слідчий, прокурор мають прийняти для себе рішення, що таке майно має для справи доказове значення. Утім, відповідно до закону, рішення слідчого, прокурора приймається у формі постанови, що ще раз аргументує позицію автора.
\end{abstract}

Ключеві слова: арешт майна, речовий доказ, майно, на яке може бути накладено арешт, заходи забезпечення кримінального провадження, ухвала слідчого судді, клопотання слідчого.

The article deals with the urgent for modern law enforcement practice issue of adoption of a decree on the admission of property as an evidence, as a prerequisite for its seizure. Generalization of law enforcement practice shows that in Ukraine there is no united approach of investigators, prosecutors and investigating judges to solve this question. There are no common approaches among scientists too. Interpretation of the relevant rules of criminal procedural legislation also does not allow concluding on the stages of seizing of property due to lack of legal certainty in the legal norms. The counter-argumentation on the need to adopt a decree on acknowledging the object as a material evidence is the opinion of scientists, in which they state that such model does not formally contradict the law, but does not correspond to the new concept of the legal nature of evidence, according to which during the pre-trial investigation the parties collect materials about sources of future evidence that can only be recognized as evidence after their assessment only by the court.

(C) КОТОВА О.С. - аспірантка кафедри кримінального процесу (Національний юридичний університет імені Ярослава Мудрого) 
Besides, there is an opinion among scientists that tending to adopt a decree on recognition of objects as material evidence, the prosecution thus preserves the practice that existed under the CPC of Ukraine in 1960, according to which the investigator and the prosecutor recognized the data collected and evaluated by them as an evidence. However, such practice is outdated and does not correspond to current legislation. Author of the article on the basis of generalization of judicial and investigative practice concludes about the expediency and validity of the adoption of the decree on recognition of objects (property) as physical evidence before deciding the issue of seizure of such property and reasons his opinion. In particular, it is highlighted that the seizure of property is allowed in order to ensure the preservation of material evidence, that is, at the time of judicial hearing of the issue of seizure of property, the investigator, the prosecutor are to decide for themselves that this property is of probative value for the case. Meanwhile, according to law, the decision of the investigator, the prosecutor is made in the form of a decree, which once again supports the author's position.

Key words: seizure of property, physical evidence, property, which can be seized, measures to ensure criminal proceedings, ruling of the investigating judge, decision of the investigator.

Вступ. Починаючи з 2012 р., коли було прийнято новий Кримінальний процесуальний кодекс України (далі - КПК), в науковій спільноті не припиняється дискусія, предметом якої є питання винесення постанови про визнання речовим доказом (винесення якої було передбачено попереднім КПК 1960 р., але не згадується у КПК 2012 р). Водночас вироблення чіткої позиції з цього питання $є$ надважливим не лише для доктрини кримінального процесу, але й для забезпечення єдності у правозастосовній діяльності.

Питання винесення постанови про визнання речовим доказом піднімалось в роботах таких учених, як В.В. Вапнярчук, І.Ю. Кайло, С.О. Ковальчук, І.О. Крицька, Л.М. Лобойко, О.Ю. Хахуцяк, О.Г. Шило, М.С. Шумило та інші. Водночас погляд на вказану проблему насамперед здійснювався через призму коректного оформлення доказового матеріалу на стадії досудового розслідування. Тож у частині розгляду цього питання в контексті прийняття рішення про арешт майна зазначена проблематика зберігає резерв для подальшого наукового дослідження.

Постановка завдання. Мета дослідження полягає у здійсненні системного аналізу наукових позицій і правозастосовної практики задля з'ясування питання допустимості, необхідності та доцільності винесення постанови про визнання предмета речовим доказом як передумови прийняття рішення про арешт майна.

Результати дослідження. Однією із цілей арешту майна закон називає збереження речових доказів (п. 1 ч. 2 ст. 170 КПК). У свою чергу, ч. 3 ст. 170 КПК націлює на те, що 3 метою збереження речових доказів арешт накладається на майно будь-якої фізичної або юридичної особи за наявності достатніх підстав вважати, що воно відповідає критеріям, які висуваються до речових доказів. Указані законодавчі положення, по суті, стали підгрунтям для відносно стабільної судової практики, яка розглядає факт винесення слідчим, прокурором постанови про визнання предмета речовим доказом обов'язковою передумовою накладення арешту на такий предмет ${ }^{1}$. Водночас чинний КПК (на відміну від КПК 1960 р. (ч. 1 ст. 79), а також кодексів деяких інших держав (наприклад, Республіки Казахстан, Республіки Молдова, Російської Федерації)) не містить прямої вимоги щодо необхідності винесення постанови про визнання матеріального об'єкта речовим доказом [1, с. 111]. Зазначене, у свою чергу, породило дискусію із цього питання в наукових колах, результатом якої стала поява двох діаметрально протилежних підходів.

Наприклад, учені-прихильники складання згаданого процесуального документа наполягають не лише на можливості в умовах чинного законодавства, а й на необхідності винесення слідчим, прокурором постанови про визнання предмета речовим доказом. Зокрема, як указує О.Г. Шило, «... хоча закон і не передбачає складання окремої постанови про залучення до кримінального провадження предметів як речових доказів, таке процесуальне рішення забезпечує визначеність у цьому питанні і з урахуванням ч. 2 ст. 100 КПК вбачається доцільним» [2, с. 81]. На доцільності складання вказаного документа наполягає й В.В. Вапнярчук, вказуючи: «... винесення такої постанови, по суті, $є$ констатацією рішення слідчого, прокурора використати певну річ як речовий доказ. <..> Тобто така постанова має передусім організаційно-розпорядчий характер»

1 Приклади з практики буде наведено далі. 
[3, с. 300-301]. Схожий підхід демонструє й С.О. Ковальчук [див.: 4, с. 112-113]. До висловлених позицій долучається І.О. Крицька, наводячи додаткову аргументацію на підтвердження позиції про необхідність і доцільність винесення постанови про визнання предмета речовим доказом і приєднання його до матеріалів провадження. Як указує авторка, «по-перше, винесення слідчим, прокурором постанови про визнання матеріального об'єкта речовим доказом не означає, що ці учасники вирішують наперед замість суду питання про належність, допустимість і достовірність певного доказу. Усі вони є самостійними суб'єктами оцінки доказів, яку вони здійснюють на певних етапах і стадіях кримінального провадження, приймаючи відповідні процесуальні рішення. По-друге, наявність або відсутність постанови відіграє важливу роль для вирішення питання про законність обмеження права власності щодо майна, яке було тимчасово вилучено та на яке було накладено арешт» [1, с. 114-115]. О.Ю. Хахуцяк, апелюючи до необхідності чіткості та визначеності в процедурі оформлення речових доказів і передання їх на зберігання, йде ще далі і пропонує внесення змін до КПК, спрямованих на відродження раніше наявного правила. Зокрема, авторка доводить, що «... якщо слідчий, прокурор отримують певний матеріальний об'єкт, що має значення для кримінального провадження, у них після проведення огляду або дослідження цього предмета $є$ необхідність (якщо немає підстав на повернення його володільцю) направити цей предмет на збереження до компетентних осіб, де він має перебувати до прийняття кінцевого рішення судом. Отже, слідчий, прокурор визнають за необхідне скласти постанову про долучення до провадження речового доказу і передають разом із копією постанови предмет на збереження компетентним особам, які, отримавши цей предмет із постановою слідчого, мають надати останньому квитанцію про отримання речового доказу $<\ldots>3$ урахуванням викладеного пропонується внести доповнення до ч. 3 ст. 98 КПК України, де передбачити таке: «Слідчий, прокурор після проведення усіх необхідних дій з матеріальним об’єктом, який має значення для кримінального провадження, виносить постанову про його залучення до провадження як речового доказу». Це доповнення КПК України, по-перше, надаватиме речовому доказу його реального юридичного значення; по-друге, стане гарантією належної правової процедури кримінального провадження» $[5$, c. 47,48$]$.

Водночас у науковій спільноті є й досить численна група процесуалістів-супротивників винесення постанови про визнання предмета речовим доказом і приєднання його до матеріалів провадження. Наприклад, І.Ю. Кайло наполягає на тому, що «... брак у новому кримінальному процесуальному законодавстві вказівки на обов'язок слідчого виносити розглядувану постанову все ж $є$ не випадковістю, а органічним складником цілісної концепції. <...> Сьогодні винесення слідчим постанови про визнання предмета речовим доказом хоч формально й не суперечить законодавству (зважаючи на ч. 3 ст. 110 КПК), проте не відповідає новітній концепції сприйняття доказів загалом» [6, с. 107-108]. При цьому висновок дослідника спирається на спробу критичного переосмислення ідеології нормативної моделі поняття «доказ» у КПК, зроблену в роботі M.Є. Шумила, яка надала науковцю можливість вказати таке: «Під час досудового розслідування сторони збирають матеріали про джерела майбутніх доказів - носіїв даних про факти й обставини, що підлягають доказуванню. Зібрані сторонами матеріали $<\ldots .>$ можуть визнаватися доказами за результатами їх інтерпретації лише судовим органом» $[7$, с. 48$]$. Показово, що висновки M.Є. Шумила й іншими дослідниками були сприйняті саме як контраргументація необхідності винесення постанови про визнання предмета речовим доказом. Наприклад, аналізуючи цитовану роботу, I.О. Крицька інтерпретувала її так: «М.Є. Шумило також припускає, що, можливо, законодавець не випадково «забув» про необхідність винесення постанови про визнання предмета речовим доказом, а керувався тим, що ані слідчий, ані жоден інший суб'єкт, окрім суду, не може приймати рішення про те, що певні фактичні дані повинні набути значення доказу в кримінальному провадженні, доки вони не будуть оцінені під час судового розгляду» [1, с. 112]. Критику підходу, який передбачає винесення постанов про визнання предметів речовими доказами, висловлює й Л.М. Лобойко, зазначаючи, що «... сторона обвинувачення прагне зберегти практику, яка існувала за КПК України 1960 р., згідно з якою слідчий і прокурор визнавали доказами дані, зібрані й оцінені ними, у зв'язку з чим у практиці досудового розслідування, здійснюваного за чинним КПК України, слідчі продовжують складати постанову про визнання предметів речовими доказами і приєднання їх до матеріалів кримінального провадження. Це ставить сторону захисту в очевидно невигідне становище й свідчить про існування в реальних кримінальних провадженнях невиправданої переваги сторони обвинувачення» [8, с. 86].

Однак, як уже зазначалось, вивчення нами цього питання крізь призму сучасної судової практики застосування арешту майна надає можливість констатувати у правозастосуванні від- 
носно стабільну тенденцію: судді розцінюють факт винесення слідчим, прокурором постанови про визнання предмета речовим доказом як обов'язкову передумову накладення арешту на такий предмет. На доведення вказаної тези та для демонстрації логіки міркувань представників судової гілки влади наведемо кілька цитат із відповідних судових рішень. Наприклад, скасовуючи арешт майна як необгрунтований, слідчий суддя Печерського районного суду м. Києва у мотивувальній частині відповідної ухвали вказав таке: «Слідчий суддя враховує ту обставину, що орган досудового розслідування, звертаючись із клопотанням про арешт майна 3 метою забезпечення збереження речового доказу, першочергово має визнати майно, на яке він просить накласти арешт, речовим доказом у кримінальному провадженні шляхом винесення про це постанови, в якій має зазначити підстави визнання майна речовим доказом, з огляду на положення ст. 98 КПК України. Проте таких дій органом досудового розслідування вчинено не було, в матеріалах із розгляду клопотання відсутня постанова про визнання грошових коштів на банківських рахунках ТОВ «Хорос» речовими доказами, як і не зазначено та належним чином не обгрунтовано, як грошові кошти мають стосунок до кримінального провадження, які саме сліди вчинення злочину могли залишитися на них і чи можна взагалі їх використовували як речовий доказ у кримінальному провадженні. Наведені обставини свідчать про відсутність підстав для накладення арешту саме з метою забезпечення збереження речового доказу, а іншої мети ініціатором клопотання про накладення арешту не було зазначено» ${ }^{2}$ [9]. Ідентичне обгрунтування слідчим суддею Печерського районного суду м. Києва наведено й в мотивувальній частині ухвали про скасування арешту з рахунків ТОВ «Аліт» [див.: 10]. Слідчий суддя Берегівського районного суду Закарпатської області відмовив у задоволенні клопотання про накладення арешту на майно, оскільки «... до клопотання не додано доказ визнання речовими доказами грошових коштів, на які слідчий просить накласти арешт, такий також не надано і в судовому засіданні» [11]. Слідчий суддя Ужгородського міськрайонного суду Закарпатської області, відмовляючи в задоволенні клопотання про арешт майна, послався на те, що «... суд встановив, що слідчим не обгрунтовано необхідність застосування такого заходу забезпечення кримінального провадження, як арешт майна, саме 3 метою збереження речових доказів, оскільки до клопотання не додано доказ визнання речовими доказами транспортного засобу, на який слідчий просить накласти арешт» [12]. Відмовляючи в накладенні арешту на групу речей ${ }^{3}$, слідчий суддя Берегівського районного суду Закарпатської області обгрунтував своє рішення так: «Слідчий зазначив, що ці речі визнані речовим доказом, однак постанову про визнання речовим доказом у судовому засіданні надати не зміг. $<\ldots .>$ До клопотання не додано доказ визнання речовими доказами речей, на які слідчий просить накласти арешт, такий також не надано і в судовому засіданні» [13]. Слідчий суддя Індустріального районного суду м. Дніпропетровська дійшов висновку про необхідність відмовити у накладенні арешту на річкове судно, оскільки «... прокурором у клопотанні про арешт майна не наведено обгрунтованих підстав, у зв'язку з якими потрібно накласти арешт, в матеріалах самого клопотання взагалі відсутня постанова про визнання речовим доказом судна «Николай Савицкий» [14]. Відмовляючи в накладенні арешту на майно, слідчий суддя Тернівського районного суду м. Кривого Рогу Дніпропетровської області пояснив своє рішення так: «... слідчий, прокурор, який вважає за потрібне звернутись до слідчого судді з клопотанням про арешт майна з метою забезпечити збереження його як речового доказу, першочергово мав би визнати майно, на яке він просить накласти арешт, речовим доказом у кримінальному провадженні шляхом винесення про це постанови, в якій зазначити підстави для визнання майна речовим доказом, з огляду на положення ст. 98 КПК України. Проте таких дій вчинено не було з огляду на відсутність у доданих до

2 Принагідно зауважимо, що, як справедливо зазначено в цитованій ухвалі суду, грошові кошти в безготівковій формі на банківських рахунках навряд чи взагалі можна вважати речовими доказами. Зокрема, як зазначив слідчий суддя у вказаній ухвалі, «... грошові кошти у безготівковій формі на банківському рахунку (без найменування номіналів купюр, їхніх серійних номерів та інших родових та індивідуальних ознак, властивих для готівкових коштів), не підпадають під визначення речових доказів у кримінальному провадженні, оскільки не є матеріальними об'єктами, які можуть зберегти сліди злочинів. Належними та допустимими речовими доказами в цьому випадку могли б бути документи про рух коштів, отримані в установленому законом порядку (ст. 160, 162 КПК України»).

3 Йшлося про «прозорий полімерний пакет із речовиною рослинного походження зеленувато-сірого кольору, схожою на скручене листя коноплі, сім уламків медичних шприців, прозорого полімерного пакету із порошкоподібною речовиною білого кольору, полімерну банку з надписом «100\% Creatine 500 Gr» 3 порошком білого кольору та полімерну банку з надписом «100\% Micronized Creatine» 3 порошком білого кольору». 
клопотання матеріалах постанови про визнання майна речовим доказом» $[15]^{4}[$ до примітки див.: 16; 17].

Проаналізувавши вищенаведені наукові позиції та підходи, що превалюють у правозастосовній практиці, маємо долучитися до групи науковців, які відстоюють необхідність і доцільність винесення слідчим, прокурором постанови про визнання предмета речовим доказом. При цьому з урахуванням предмета нашого дослідження спробуємо надати зазначеному підходу додаткової аргументації саме через призму специфіки застосування арешту майна. У цьому ключі зазначимо, що, на наше переконання, логіка суддів, які розцінюють факт винесення слідчим, прокурором постанови про визнання предмета речовим доказом як обов'язкову передумову накладення арешту на такий предмет $є$ правильною і полягає в такому. Відповідно до вимог КПК «... арешт майна допускається з метою забезпечення збереження речових доказів» (п. 1 ч. 2 ст. 170 КПК). Тобто на момент судового розгляду питання про накладення арешту на майно слідчий, прокурор (принаймні для себе) мають прийняти рішення, що таке майно має для справи доказове значення, а саме́ майно має набути процесуального статусу речового доказу. Навіть якщо обгрунтування того, що предмет має доказове значення для кримінального провадження, викладено в клопотанні про накладення арешту, формально для судді це не може вважатися процесуальним рішенням, оскільки, відповідно до закону, рішення слідчого, прокурора приймається у формі постанови (ч. 3 ст. 110 КПК). На підтвердження висловленої гіпотези наведемо цитату із судового рішення, де вказана логіка міркувань простежується особливо яскраво. Зокрема, слідчий суддя Солом'янського районного суду міста Києва, відмовляючи в задоволенні клопотання про накладення арешту на майно, мотивував своє рішення так: «Аналізуючи наведені вимоги закону, слідчий суддя вважає, що висновок органу досудового розслідування щодо відповідності майна тим чи іншим ознакам ст. 98 КПК України може бути зроблено лише в тексті постанови, яка має відповідати вимогам ч. 5 ст. 110 КПК України, зокрема містити мотиви прийнятого рішення. Відсутність постанови про визнання майна речовим доказом як окремого процесуального документа, який фіксує висновок слідчого про набуття майном статусу речового доказу та мотиви, 3 яких він дійшов такої думки, позбавляє слідчого суддю можливості провести аналіз і зробити висновок про відповідність цього майна положенням ст. 98 КПК України та наявність чи відсутність підстав для арешту майна саме з метою його збереження як речового доказу, оскільки слідчий суддя не наділений правом самостійного визначення підстав, передбачених ст. 98 КПК України, та має здійснювати контроль правильності прийнятого слідчим рішення. Слідчому судді не надано слідчим постанови про визнання майна речовим доказом, що свідчить про відсутність підстав для накладення арешту саме з метою забезпечення збереження речового доказу, оскільки без відповідної постанови майно не може набути статусу речового доказу, а іншої мети клопотання слідчого не містить» [18].

У ключі вищевикладеного маємо також висловитися з приводу позиції окремих дослідників щодо строків винесення постанови про визнання речовим доказом у контексті накладення арешту. Наприклад, I.О. Крицька, розглядаючи це питання, вказує таке: «Наявність або відсутність постанови відіграє важливу роль для вирішення питання про законність обмеження права власності щодо майна, яке було тимчасово вилучено та на яке було накладено арешт. Наприклад, враховуючи, що клопотання слідчого, прокурора про арешт тимчасово вилученого майна повинно бути подано не пізніше наступного робочого дня після вилучення майна, а у разі тимчасового вилучення майна під час обшуку, огляду, здійснюваних на підставі ухвали слідчого судді, передбаченої ст. 235 КПК, клопотання про арешт такого майна повинно бути подано слідчим, прокурором протягом 48 годин після вилучення майна, по суті, арешт може бути накладений на майно, яке не має значення для кримінального провадження. Однак слідчий, прокурор не можуть встановити це без, наприклад, залучення експерта та проведення експертизи, що, зрозуміло, вимагає більше часу, ніж один день. Зважаючи на викладене, видається доцільним передбачити у КПК необхідність винесення слідчим, прокурором постанови про визнання матеріального об'єкта ре-

4 У контексті наведеної судової практики цікаво зазначити, що позиція про необхідність винесення ухвали про визнання предмета речовим доказом настільки міцно укорінилась у професійній правосвідомості суддів, що інколи навіть призводить до викривлення суддями тексту закону під час посилання на відповідні законодавчі норми в судових рішеннях. Зокрема, в окремих ухвалах судді вказують, що «... згідно 3 ч. 3,10 ст. 170 КПК України допускається накладення арешту на майно будь-якої фізичної або юридичної особи, якщо воно визнано речовим доказом (курсив - О. К.) і відповідає критеріям, зазначеним у ст. 98 КПК України щодо речових доказів». Хоча ані ч. 3, ані ч. 10 ст. 170 КПК не містить вимоги про попередню необхідність визнання предмета речовим доказом 
човим доказом не пізніше п'яти днів із моменту вилучення такого об'єкта. Слідчий, прокурор повинні навести мотиви прийнятого рішення. При цьому, якщо для визнання таких матеріальних об'єктів речовими доказами потрібно призначення експертизи, постанова про визнання їх речовими доказами повинна бути винесена не пізніше наступного робочого дня після отримання слідчим або прокурором відповідного висновку експерта. Відсутність постанови про визнання матеріального об'єкта речовим доказом повинна розглядатися як підстава для скасування арешту майна та повернення його власнику» [1, с. 115]. Визнаючи наявність раціонального зерна в процитованій позиції, все ж маємо вказати на ії дискусійність у частині обгрунтування неможливості винесення постанови про визнання предмета речовим доказом до вирішення питання про накладення арешту на майно, а відтак й пропозиції автора про винесення такої постанови вже після позитивного вирішення питання про арешт майна. Окрім того, що такий підхід суперечить наявній сьогодні судовій практиці ${ }^{5}$, на наше переконання, визнання предмета речовим доказом на момент прийняття рішення про арешт майна повинне мати характер обгрунтованого припущення (а не достовірно встановленого факту). Проводячи паралель із поняттям «обгрунтована підозра», зазначимо, що для визнання предмета речовим доказом на момент прийняття рішення про накладення на нього арешту досить існування фактів або інформації, які можуть переконати об'єктивного спостерігача в тому, що предмет, про який ідеться, може мати доказове значення для кримінального провадження [в контексті поняття «обгрунтована підозра» див.: 19-21]. Саме тому постанова про визнання речовим доказом має містити обгрунтування рішення про визнання предмета речовим доказом (наприклад, вказівку на: свідків, які описували саме цей предмет; специфіку ушкоджень, які могли бути завдані саме цим предметом; наявність крові на предметі тощо). Безперечно, подальше експертне дослідження може як посилити, так і знівелювати вказане обгрунтування, перетворивши знання про речовий доказ із обгрунтованого припущення на достовірність, але на момент прийняття рішення про накладення арешту на майно цього не вимагається. В цьому ключі також маємо вказати, що самого по собі факту існування постанови про визнання предмета речовим доказом не досить для суду під час прийняття рішення про арешт майна 3 метою збереження його як речового доказу. Достатність обгрунтування припущення слідчого, прокурора щодо того, що річ може бути речовим доказом у кримінальному провадженні, перевіряється судом під час розгляду питання про арешт майна, що підтверджується відповідними судовими рішеннями. Наприклад, скасовуючи арешт зернових культур, що належать ТОВ «Девайс ЛТД», слідчий суддя Печерського районного суду м. Києва мотивував своє рішення так: «Прокурором у судовому засіданні не доведено відповідність майна, на яке накладено арешт, критеріям, визначеним ст. 98 КПК України. При цьому долучена прокурором до матеріалів клопотання постанова про визнання вказаних зернових речовими доказами в кримінальному провадженні також таких даних не містить. Приймаючи таке рішення, прокурор обмежився виключно цитуванням ст. 98 КПК України, без будь-якої вказівки про можливу належність арештованого майна до речових доказів» [22].

Висновки. Проведене дослідження та наведена аргументація дають нам можливість зробити висновок про допустимість із погляду чинного КПК, а також доцільність і виправданість винесення постанови про визнання предметів (майна) речовими доказами перед вирішенням питання про накладення арешту на таке майно.

\section{Список використаних джерел:} 2018. $280 \mathrm{c}$.

1. Крицька І.О. Речові докази у кримінальному провадженні : монографія Харків : Право,

2. Шило О.Г. Речові докази як процесуальне джерело доказів. Вісник прокуратури. 2013. № 6 (144). C. 76-83.

3. Вапнярчук В.В. Теорія і практика кримінального процесуального доказування : монографія. Харків : Юрайт, 2017. 408 с.

4. Ковальчук С.О. Вчення про речові докази у кримінальному процесі: теоретико-правові та практичні основи : дис. ... д-ра юрид. наук : 12.00.09. Одеса, 2018. 626 с.

5. Хахуцяк О.Ю. Речові докази у новому Кримінальному процесуальному кодексі України. Адвокат. 2013. № 6. С. 46-48.

6. Кайло І.Ю. Допустимість доказів у кримінальному процесі України : дис. ... канд. юрид. наук. Харків, 2016. 218 с.

5 Розумісмо, що вказане не може служити контраргументом позиції I.О. Крицької, оскільки позиція авторки сформульована не у формі de lege lata, а у формі de lege ferenda. Тож ця теза є лише уточненням. 
7. Шумило М.Є. Поняття «докази» у Кримінальному процесуальному кодексі України: спроба критичного переосмислення ідеології нормативної моделі. Вісник Верховного Суду України. 2013. № 2. С. 40-48. URL: http://nbuv.gov.ua/UJRN/vvsu_2013_2_10.

8. Лобойко Л.М. Співвідношення даних досудового розслідування і доказів. Право України. 2014. № 10. С. 82-88.

9. Ухвала слідчого судді Печерського районного суду м. Києва від 27 вересня 2017 р., справа № 757/41425/17-к. URL: http://reyestr.court.gov.ua/Review/69159576.

10. Ухвала слідчого судді Печерського районного суду м. Києва від 27 вересня 2017 р., справа № 757/41408/17-к. URL: http://www.reyestr.court.gov.ua/Review/69159323.

11. Ухвала слідчого судді Берегівського районного суду Закарпатської області від 29 травня 2017 p., справа № 297/1178/17. URL: http://reyestr.court.gov.ua/Review/66796835.

12. Ухвала слідчого судді Ужгородського міськрайонного суду Закарпатської обл. від 31 травня 2017 р., справа № 308/3772/17. URL: http://reyestr.court.gov.ua/Review/67522343.

13. Ухвала слідчого судді Берегівського районного суду Закарпатської області від 12 травня 2017 р., справа № 297/1033/17. URL: http://reyestr.court.gov.ua/Review/66475085.

14. Ухвала слідчого судді Індустріального районного суду м. Дніпропетровська від 7 грудня 2018 р., справа № 202/7734/18 1кс/202/9092/2018. URL: http://reyestr.court.gov.ua/ Review/78388178.

15. Ухвала Тернівського районного суду м. Кривого Рогу Дніпропетровської обл. від 15 червня 2018 р., справа № 215/1910/18. URL: http://www.reyestr.court.gov.ua/Review/74788926.

16. Ухвала Донецького апеляційного суду від 22 липня 2019 р., справа № 237/3606/19. URL: http://reyestr.court.gov.ua/Review/83278406.

17. Ухвала Донецького апеляційного суду від 16 липня 2019 р., справа № 237/3470/19. URL: http://reyestr.court.gov.ua/Review/83077827.

18. Ухвала слідчого судді Солом'янського районного суду м. Києва від 5 лютого 2018 р., справа № 760/3367/18. URL: http://reyestr.court.gov.ua/Review/75005938.

19. Case of Fox, Campbell and Hartley v. The United Kingdom, 30 August 1990, (Application no. $12244 / 86 ; 12245 / 86 ; 12383 / 86)$. URL: http://hudoc.echr.coe.int/rus?i=001-57721.

20. Case of Nechiporuk and Yonkalo v. Ukraine, 21 April 2011, (Application no. 42310/04). URL: http://hudoc.echr.coe.int/rus?i=001-104613.

21. Case of Murray v. The United Kingdom, 28 October 1994, (Application no. 14310/88). URL: http://hudoc.echr.coe.int/rus?i=001-57895.

22. Ухвала слідчого судді Печерського районного суду міста Києва від 19 вересня 2017 р., справа № 757/53580/17-к. URL: http://reyestr.court.gov.ua/Review/68970206. 